\title{
Study on Silkworm Bed Cleaning Frequency during Larval Growth Period
}

\author{
Abiy Tilahun*, Kedir Shifa, Ahmed Ibrahim and Metasebia Terefe \\ Ethiopian Institute of Agricultural Research, Melkassa Agricultural Research Center, P.O. Box: 436, \\ Melkassa, Ethiopia
}

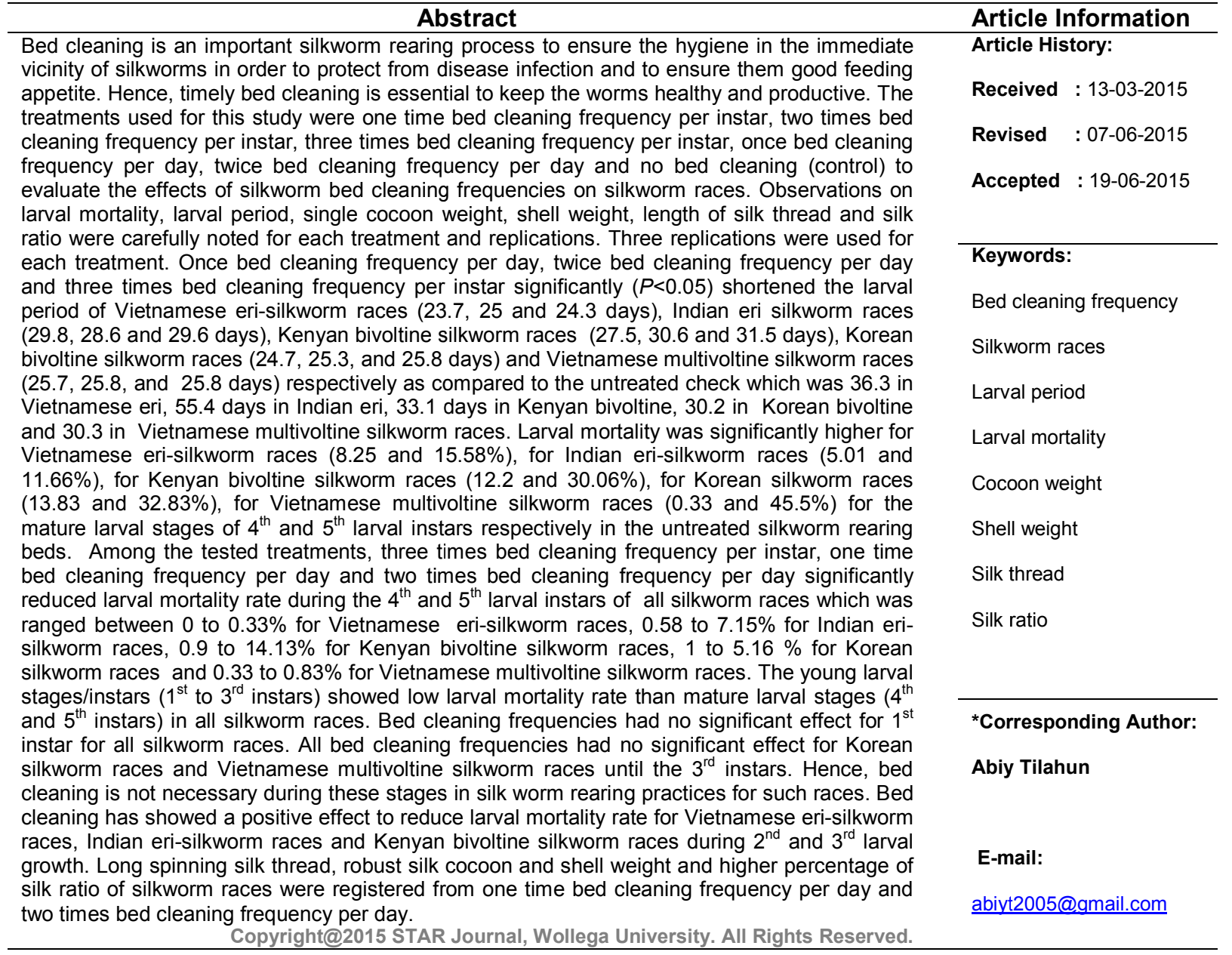

\section{INTRODUCTION}

Sericulture is the process of obtaining the natural silk fiber through silk worm rearing, which can be practiced in varying agro-climatic conditions, and is suited to different production systems (Singh et al., 2002). Ethiopia is granted with diversified climate, vegetation and topography. This is also true for diversified options of sericulture industry which are adopted on different vegetation (for feeding of silk-worms) and different species of silkworms (Metaferia et al., 2007). FAO (1976) published that silk production is a highly profitable business enterprise that can produce a lucrative return from small portion of land where most of the land can be used for other food crops production. In Ethiopia, agricultural production is of a subsistence nature. Poverty and unemployment are the main challenges to the population, which therefore, requires additional on farm and off farm income generation technologies like raising of silkworms (silk production) (Metaferia et al., 2007). As a 
Abiy Tilahun et al.,

result, silk production from eri silkworm (Samia cynthia ricini), a polyphagous insect, its primary feed plant (castor (Ricinus communis L.) (Raghavaiah 2003b), and mulberry silkworm (Bombyx mori), a monophagous insect, feeds on only mulberry plant (Morus species) (Takano and Arai 1978) are commonly practiced in Ethiopia currently. Even though it is recently introduced in the country, promising results have been recorded in terms of generation of income and creation of employment opportunities (Metaferia et al., 2007). Silkworm rearing is an extensive month-long exercise starting from egg stage and terminating in adults laying eggs and dying their natural death. During this course, they pass through five larval instars $\left(1^{\text {st }}, 2^{\text {nd }}, 3^{\text {rd }}, 4^{\text {th }}\right.$, and $5^{\text {th }}$ instars $)$ intervened by four moults, cocoon and pupal stage (Singh et al., 2002). Silkworm rearing effectively means the culturing of five larval instars as other stages like egg, pupa and adults are non-feeding stages. In Ethiopia, whole life cycle spans through 46-56 days with 10-13 days of egg stage, 21-30 days of larval stage, 2-3 cocoon spinning days, 10-15 days as pupal duration and 3-5 days in adult stage (Abiy et.al unpublished). During larval growth stage bed cleaning is an important silkworm rearing process to ensure the hygiene in the immediate vicinity of silkworms in order to protect from disease infection and to ensure them good feeding appetite (Gogoi and Goswami 1998). The larvae should feed with appropriate quantity of leaves and feeding frequency based on the age/size of the larvae and their population in the bed (Ahmed et.al unpublished). Silkworms do not consume all the leaves that are supplied to them and invariably a part of the feed is left behind on the rearing bed. At the same time the larvae also defecate and their feces remaining on the rearing bed. If the residual leaves and the fecal matter are left on the rearing bed for some time, both start decomposing and fermenting there by quickly increasing the dampness of the bed. This adversely affects the larval physiology (Reddy and Swamy 1999). Therefore, it is essential to periodically remove these materials from the bed and keep it clean. The process of doing is known as bed cleaning.

Dried leaves, rejected leaf in the bed, silk worm's excreta, exuviae, dead worms, diseased larvae all will increase the humidity, fermentation and temperature in the bed (Reddy and Swamy 1999). The authors further indicated that prevailing environmental conditions especially, temperature and relative humidity are vital in determining silkworm physiology as it is a cold-blooded organism. As soon as the larvae grow-up, the unconsumed leaves and litter increase in the rearing bed which ultimately cause changing atmosphere and favoring multiplication of pathogenic organisms such as protozoa, fungi, bacteria and viruses (Sannappa and Jayaramaiah 1999). Hence, bed cleaning should be done to remove fecal matter, dead worms and leaf remnants which would promote fungal, bacterial and viral infections (Sannappa and Jayaramaiah 1999). Diseases are the behavioral and physiological changes induced by pathogens in an organism (Hisao, 2001). If proper bed cleaning is not done in time it leads to various complications viz. ill health of larvae, disinterest of the larvae to feed due to unhygienic conditions, ultimately worms become weak and low in productivity (Hisao, 2001).Since they cause substantial financial loss to the silk producers, their prevention and control assumes utmost importance. Hence, timely bed cleaning is essential to keep the worms healthy and productive. The frequency of bed cleaning
Sci. Technol. Arts Res. J., April-June 2015, 4(2): 39-47

studies revealed that when larvae were not cleaned more number of dead larvae was observed compared to the treated beds (Zhang,et al., 2002). They further revealed that regular bed cleaning every day minimizes the larval mortality $(0.67 \%)$. It was higher in untreated beds (2.0$23.67 \%$ ). This study indicated that the eri-silk worms allowed to clean once per day was recorded statistically significant highest cocoon weight $(3.67 \mathrm{~g})$ followed by twice per day (3.53-3.46 g). The worms on the untreated bed were recorded lowest cocoon weight (2.78-2.65 g) compared to other treatments used. The bed cleaning has influence on the shell weight and silk ratio of eri silkworms (Devaiah et al., 1985). According to their study the worms allowed for cleaning were recorded statistically significant maximum shell weight $(0.35-0.33 \mathrm{~g})$, and silk ratio (12.87 to $13.97 \%$ ) compared to the un treated check, $0.30-0.27 \mathrm{~g}$ shell weight and 9.1 to $10.22 \%$ silk ratio. They further obtained that the length of the eri silk thread was maximum in worms allowed to clean which ranged from $6.1 \mathrm{~m}$ to $5.82 \mathrm{~m}$ and this was minimum $(4.5 \mathrm{~m})$ when worms were not received bed cleaning treatment. Sakthivel (2004) observed superior larval growth, development and higher cocoon production when eri silkworms were regularly cleaned according to their age, especially at late ages of $4^{\text {th }}$ and $5^{\text {th }}$ larval instars. According to them the progressive growth of silkworms was superior when properly fed and cleaned. The silkworm culture adaptation is being practiced in a large scale on the leaves of castor and mulberry with ideal feeding to administer nourishment to all the worms simultaneously and thereby to secure uniform growth and development of the worms (Neelu et al., 2000). They further mentioned that next to feeding, cleaning is an equally important factor. It is necessary for the health and progress of the worms. Considering all these factors the ideal cleaning intervals were studied. Sharma et al., (1996) also observed that silkworms at regular bed cleaning resulted in significantly higher larval weight, larval survival, cocoon weight, shell weight, shell ratio, pupal weight, and rate of pupation, silk productivity, fecundity and egg hatching with lower larval and pupal durations than those raised under no bed cleaning condition in farmers' practices. Bed cleaning is done after every moult for the young silkworms and every other day for the mature worms by some silk producers in others it is done once per day for all ages of silkworms as a blanket recommendation. Frequent cleaning is better but it involves more labor and ultimately silkworm rearing uneconomical. The present study was therefore conducted to determine stage wise bed cleaning frequency for each larval instars of the different silkworm races reared at Melkassa sericulture laboratory. The study also sought to examine the effect of bed cleaning frequency on larval mortality, larval period and yield components of the different silkworm races.

\section{MATERIALS AND METHODS}

This experiment was carried out at Melkassa Agricultural Research Center, sericulture research laboratory between 2011 and 2013. Mulberry and erisilkworm rearing were carried out on multivoltine and bivoltine silkworm breeds in the same laboratory as per appropriate recommendations (Dayashankar, 1982). The silkworm rearing equipments were cleaned, washed, sun dried and disinfected with $2 \%$ formalin solution at the rate of $800 \mathrm{ml}$ per $10 \mathrm{~m}^{2}$ areas before the commencement of rearing (Nataraju et al., 2005). The breeds were reared following shelf rearing techniques starting from brushing 


\section{Abiy Tilahun et al.,}

till cocoon spinning. Silkworms at larval stage were fed on mulberry and castor leaves four times a day with tender leaves until $3^{\text {rd }}$ instar and mature leaves for $4^{\text {th }}$ and $5^{\text {th }}$ instars. Silkworms are fed four times in a day - morning (8-8:30 A.M.), mid-day (11:30-12:00 A.M.), after noon (2:00-2:30 P.M.) and evening (5-6 P.M.). Before bed cleaning, leaves spread on top of the feeding tray. Worms crawl up to feed. Then, the worms were shifted using the news paper to new beds and feeding is then resumed. The litter, leftover food and dead silkworms, were removed carefully and disposed off away from the rearing house. The grown up worms, after completing feeding during late fifth instar at their ripened stage (ready to spin silk) were picked and transferred on the mountages (equipment to provide support for cocoon formation) for spinning silk cocoons. Ripened silkworms were identified by their characteristics movement to the corners of the rearing beds, reduction in size and transparent yellow appearance. After six to eight days of spinning, cocoons were harvested from the mountages. Observations on larval duration, larval mortality rate and qualitative characters of the cocoon (fresh cocoon weight, cocoon shell weight, length of spinning thread and silk ratio) were recorded. Then, cocoon was boiled to make the serecin soft to dissolve. Silk filament was extracted out in which the coarser floss layer was removed. For the identification of causes of larval death, diseased larvae were examined. To grow fungal pathogens potato dextrose agar and for bacterial growth nutrient agar were applied. On the other hand, direct microscopic observation of the infected silkworm parts was used for the identification of silkworm diseases. Data such as number of infected silkworms versus total number of silkworms were recorded to determine the silkworm larval mortality rate.
Sci. Technol. Arts Res. J., April-June 2015, 4(2): 39-47

Silkworm races used for this study were Vietnamese eri-silkworm races, Indian eri silkworm races, Kenyan bivoltine silkworm races, Korean bivoltine silkworm races, and Vietnamese multivoltine silkworm races. The treatments used for this study were one time bed cleaning frequency per instar, two times bed cleaning frequency per instar, three times bed cleaning frequency per instar, once bed cleaning frequency per day, twice bed cleaning frequency per day and no bed cleaning (control). Complete randomized design with three replications was used for each treatment and 200 silkworms were brushed in each replication and allowed to complete the larval period. Statistical analysis software (SAS) was used to analyze the data using analysis of variance (ANOVA) procedure. Least significant difference (LSD) was used for mean separation. Percentage proportions were calculated for larval mortality rate.

\section{RESULTS AND DISCUSSION}

Effect of Bed Cleaning Frequency on Silkworm Larval Period: Once bed cleaning frequency per day, twice bed cleaning frequency per day and three times bed cleaning frequency per instar significantly $(P<0.05)$ shortened the larval period of Vietnamese eri-silkworm races $(23.7,25$ and 24.3 days), Indian eri silkworm races (29.8, 28.6, 29.6 days), Kenyan bivoltine silkworm races $(27.5,30.6$ and 31.5 days), Korean bivoltine silkworm races (24.7, 25.3 and 25.8 days) and Vietnamese multivoltine silkworm races $(25.7,25.8$ and 25.8 days) respectively as compared to the untreated check which was 36.3 in Vietnamese eri, 55.4 days in Indian eri, 33.1days in Kenyan bivoltine, 30.2 days in Korean bivoltine and 30.3 days in Vietnamese multivoltine silkworm races as indicated in figure 1.

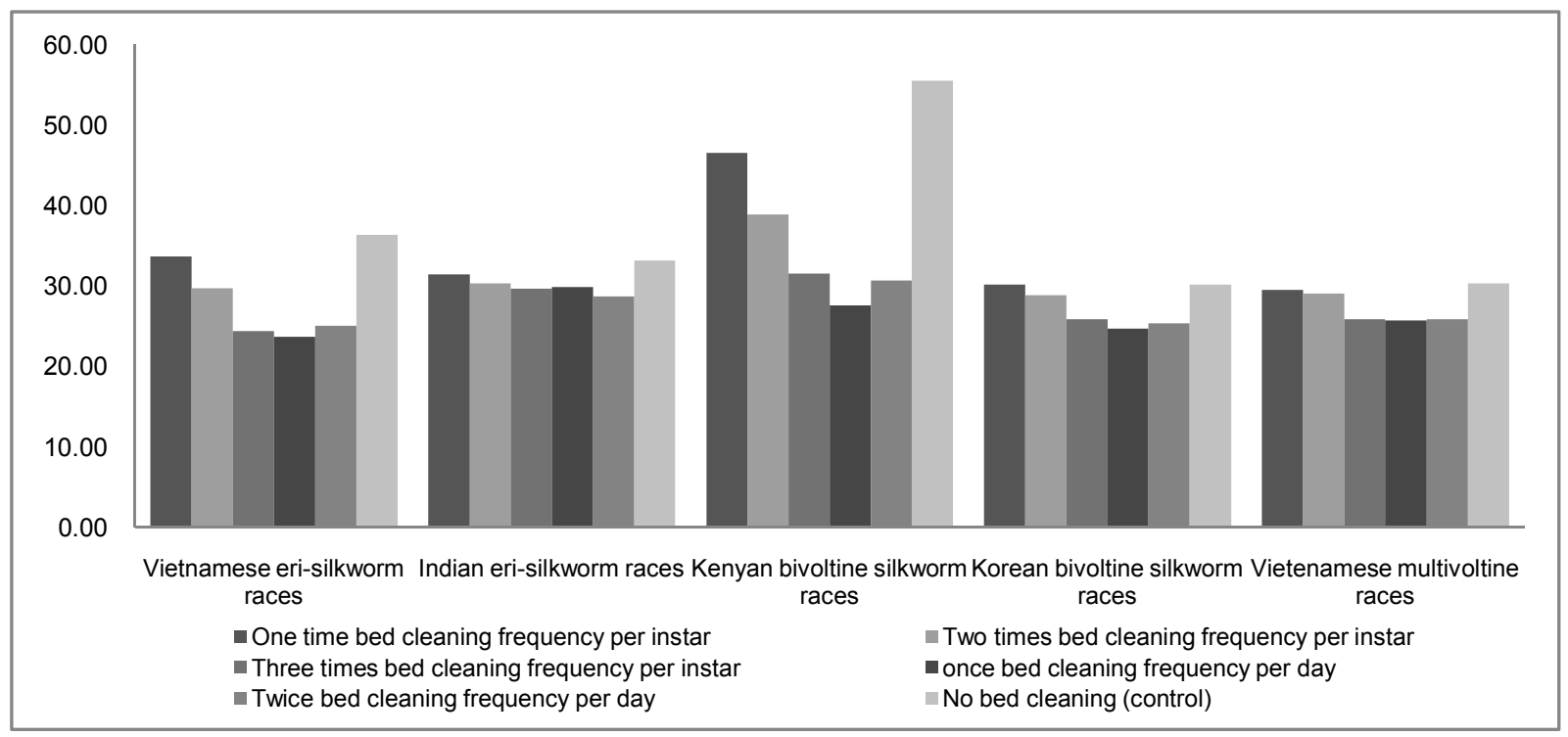

Figure 1: Effect of silkworm larvae bed cleaning frequency on larval period of different silkworm races

Sachan and Bajpai (1973a) observed the larval duration of Eri silkworm on different host plants revealed that 22-27 days were required in good silkworm rearing condition to complete the larval development. The larval period in our study falls more or less within the same range as indicated by the authors. Significantly $(P<0.05)$ longer larval growth period was registered from the untreated check (55.5 days) as opposed to the shortest larval growth period from once bed cleaning frequency per day in Vietnamese eri silkworm races (23.7 days), in Kenyan bivoltine silkworm races (27.5 days), in Korean bivoltine silkworm races (24.7 days), in Vietnamese multivoltine silkworm races (25.7 days) (figure 1).

The entire larval period $\left(1^{\text {st }}\right.$ to $5^{\text {th }}$ larval stages) ranged from 23.7 days to 31.5 days feeding on castor and 
Abiy Tilahun et al.,

mulberry host plants (Reddy, 2008). The authors observed superior larval growth and higher cocoon production when eri silkworms were received ideal feeding, spacing and bed cleaning. Further, the larvae receiving once bed cleaning frequency per day during fifth instar had better growth (Joshi, 1987). According to this author the ideal bed cleaning is to administer good health to all the worms simultaneously and thereby to secure uniform growth and development of the worms. In this study the larval period to spin cocoons (the harvested row silk) was delayed (up to 46.5 days) when the bed cleaning frequency has prolonged to one time bed cleaning frequency per instar (figure 1). With no bed cleaning situation larval period was as high as 55.5 days and in treated silkworms it was as low as 23.7 days with a difference of about 22 days (figure 1). Shorter larval period indicate fast production period of row silk and longer larval period indicate prolonged production period of row silk which could influence the number of silk production times per year.

Effect of Bed Cleaning Frequency on Mortality of Different Larval Instars and Qualitative Characters of the Cocoon of Silkworm Races

This study attempted to understand the effect of bed cleaning frequency on mortality of each larval instars $\left(1^{\text {st }}\right.$ instar up to $5^{\text {th }}$ instar larval stages) of silkworm races
Sci. Technol. Arts Res. J., April-June 2015, 4(2): 39-47

introduced from different countries. In this study qualitative characters of the silk cocoon (length of silk thread, silk cocoon weight, silk shell weight and silk ratio) were also evaluated to the different bed cleaning frequencies. Figures 2 to 6 summarizes the mean values of each larval instars mortality rate and Tables 1 to 5 summarizes qualitative characters of the silk cocoon after the $5^{\text {th }}$ larval instar was treated to the different bed cleaning frequencies.

Vietenamese Eri-silkworm Races: Bed cleaning during the $1^{\text {st }}$ instar larval growth has no significant effect on their mortality rate. A significant effect of bed cleaning was observed from $2^{\text {nd }}$ instar up to $5^{\text {th }}$ instar larval ages. The percentage of larval mortality ranged from $2.58 \%$ in the $2^{\text {nd }}$ instar to $15.58 \%$ in the $5^{\text {th }}$ instar in the control plots (figure 2). All levels of bed cleaning frequency except one time bed cleaning per instar was significantly superior in reducing larval mortality (below $0.41 \%$ ) in $2^{\text {nd }}$ and $3^{\text {rd }}$ instar (figure 2). However, for these larval stages using two times bed cleaning frequency per instar among others could be economical to save time and labor. Significant variation was observed from three times bed cleaning per instar, once bed cleaning per day and twice bed cleaning frequencies per day in $4^{\text {th }}$ and $5^{\text {th }}$ instars which showed low number of larval death (below $0.33 \%$ ).

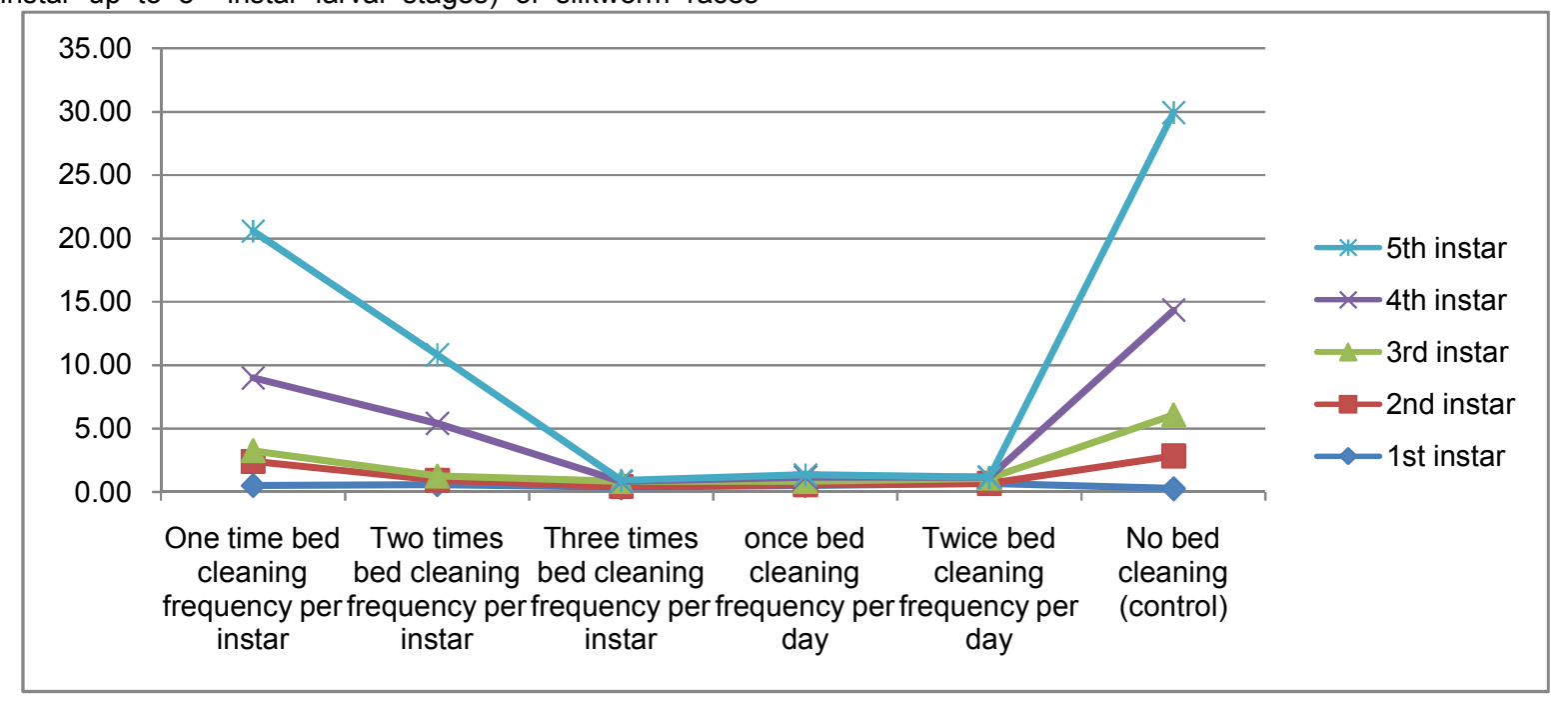

Figure 2: Effect of bed cleaning frequency on mortality of different larval instars of Vietnamese eri-silkworm races

Length of silk thread $(5.77 \mathrm{~m})$, silk cocoon weight (2.94 $\mathrm{g})$, shell weight $(0.28 \mathrm{~g})$ and silk ratio $(9.53 \%)$ were significantly $(P<0.05)$ lower when larval bed refuse and fecal matter of Vietnamese eri-silkworm larvae were not cleaned from rearing beds during their growth period than the tested bed cleaning frequencies (Table 1). Once and twice bed cleaning frequencies per day during the $5^{\text {th }}$ instar were significantly $(P<0.05)$ resulted in higher length of silk thread ( $8.65 \mathrm{~m} \& 8.51 \mathrm{~m})$, silk cocoon weight (3.43 $\mathrm{g} \& 3.44 \mathrm{~g})$, shell weight $(0.426 \mathrm{~g} \& 0.436 \mathrm{~g})$ and silk ratio $(12.50 \% \& 12.82 \%)$ as opposed to the other larval bed cleaning frequencies as indicated in Table 1.

Table 1: Effect of bed cleaning frequency on the qualitative characters of the cocoon of Vietnamese eri-silkworm races

\begin{tabular}{lcccc}
\hline \multicolumn{1}{c}{ Treatments } & $\begin{array}{c}\text { Length of } \\
\text { silk thread }(\mathbf{m})\end{array}$ & $\begin{array}{c}\text { Silk } \\
\text { cocoon weight (gm) }\end{array}$ & $\begin{array}{c}\text { Silk } \\
\text { shell weight }(\mathbf{g m})\end{array}$ & $\begin{array}{c}\text { silk ratio } \\
(\%)\end{array}$ \\
\hline One time bed cleaning frequency per instar & $6.76 \pm 0.15 \mathrm{~b}$ & $3.11 \pm 0.02 \mathrm{~b}$ & $0.306 \pm 0.003 \mathrm{~d}$ & $9.78 \pm 0.07 \mathrm{c}$ \\
Two times bed cleaning frequency per instar & $7.09 \pm 0.26 \mathrm{~b}$ & $3.28 \pm 0.06 \mathrm{a}$ & $0.33 \pm 0.005 \mathrm{c}$ & $10.02 \pm 0.22 \mathrm{c}$ \\
Three times bed cleaning frequency per instar & $8.25 \pm 0.23 \mathrm{a}$ & $3.35 \pm 0.03 \mathrm{a}$ & $0.39 \pm 0.05 \mathrm{~b}$ & $11.68 \pm 0.16 \mathrm{~b}$ \\
once bed cleaning frequency per day & $8.65 \pm 0.16 \mathrm{a}$ & $3.43 \pm 0.05 \mathrm{a}$ & $0.426 \pm 0.003 \mathrm{a}$ & $12.5 \pm 0.23 \mathrm{a}$ \\
Twice bed cleaning frequency per day & $8.51 \pm 0.52 \mathrm{a}$ & $3.44 \pm 0.06 \mathrm{a}$ & $0.436 \pm 0.003 \mathrm{a}$ & $12.82 \pm 0.16 \mathrm{a}$ \\
No bed cleaning (control) & $5.77 \pm 0.08 \mathrm{c}$ & $2.94 \pm 0.04 \mathrm{c}$ & $0.28 \pm 0 \mathrm{e}$ & $9.53 \pm 0.17 \mathrm{c}$ \\
\hline
\end{tabular}


Abiy Tilahun et al.,

Indian Eri-silkworm Races: There was no clear trend observed in the $1^{\text {st }}$ larval instar interms of larval mortality rate through applying bed cleaning frequencies. Larval mortality was significantly higher in the untreated control during $2^{\text {nd }}$ instar $(2.46 \%), 3^{\text {rd }}$ instar $(6.4 \%), 4^{\text {th }}$ instar $(5.01 \%)$ and $5^{\text {th }}$ instar $(11.66 \%)$ larval stages as opposed to all levels of cleaning frequencies (Figure 3). Significant results were achieved in reducing larval mortality rate from all levels of bed cleaning frequencies compared with the control (Figure 3). Two times bed cleaning per instar in $2^{\text {nd }}$ larval age $(0.66 \%)$, three times bed cleaning per
Sci. Technol. Arts Res. J., April-June 2015, 4(2): 39-47

instar $(0.4 \%)$ and one time bed cleaning per day $(0.28 \%)$ in $3^{\text {rd }}$ larval age, once bed cleaning per day $(0.61 \%$ and $0.58 \%)$ and twice bed cleaning per day $(11.73 \%$ and $13 \%)$ in $4^{\text {th }}$ and $5^{\text {th }}$ larval stages respectively significantly reduced larval mortality rate (Figure 3 ). Though significant results were achieved in reducing larval mortality rate in all levels of bed cleaning frequencies, the result suggested that two times bed cleaning frequency per instar for $2^{\text {nd }}$, three times bed cleaning per instar for $3^{\text {rd }}$ and once bed cleaning per day for $4^{\text {th }}$ and $5^{\text {th }}$ instars could be recommend to save time and labour.

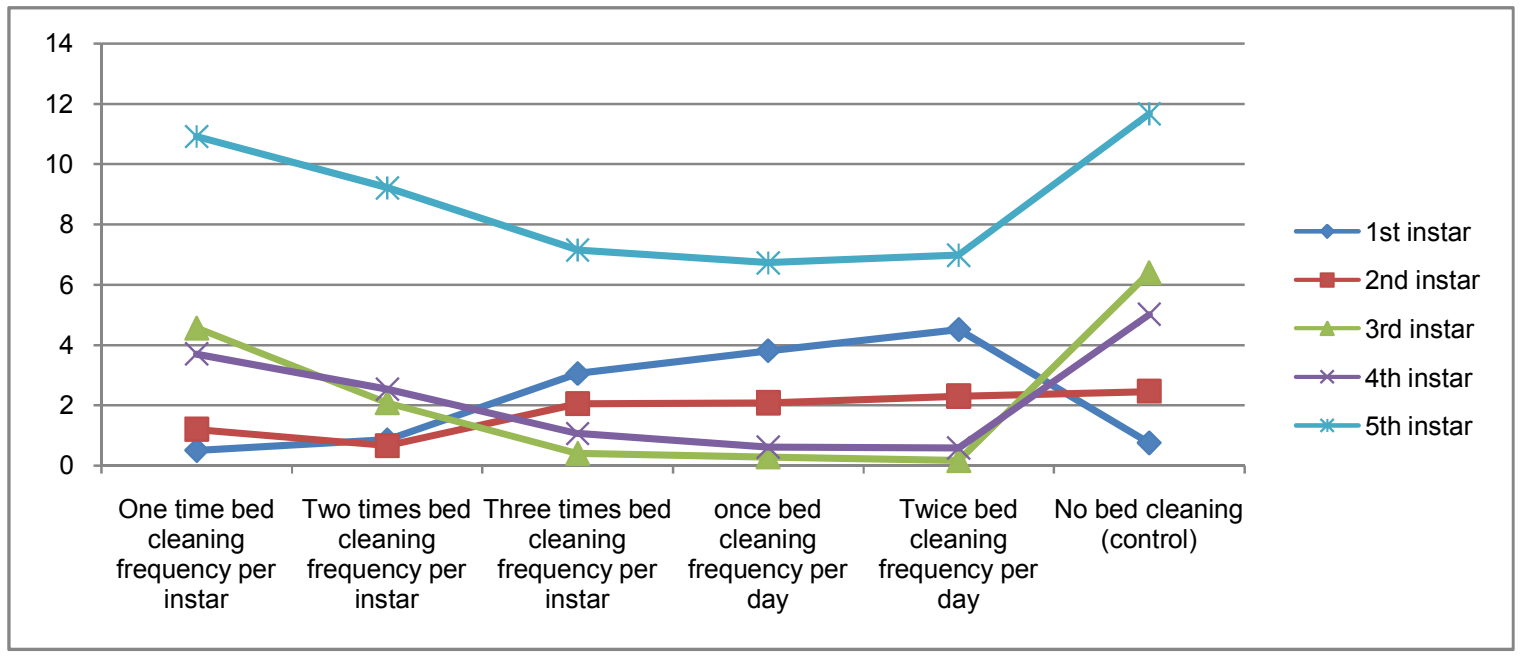

Figure 3: Effect of bed cleaning frequency on mortality of different larval instars of Indian eri- silkworm races

Length of silk thread $(8.35 \mathrm{~m}$ and $8.28 \mathrm{~m})$, and cocoon weight $(3.36 \mathrm{~g}$ and $3.38 \mathrm{~g})$, silk shell weight $(0.4 \mathrm{~g} \& 0.41$ g) and silk ratio $(11.95 \%$ to $12.21 \%$ were significantly $(P<$ 0.05 ) increased when fecal matter of silkworm larvae and other left over's (dead worms and leaf remnants) cleaned in once bed cleaning frequency per day and twice bed cleaning frequency per day. In the control beds length of silk thread, silk cocoon weight, silk shell weight and silk ratio were greatly reduced to $5.9 \mathrm{~m}, 2.87 \mathrm{~g}, 0.246 \mathrm{~g}$ and $8.72 \%$ respectively (Table 2 ).

Table 2: Effect of bed cleaning frequency on the qualitative characters of the cocoon of Indian eri- silkworm races

\begin{tabular}{lcccc}
\hline \multicolumn{1}{c}{ Treatments } & $\begin{array}{c}\text { Length of } \\
\text { silk thread }(\mathbf{m})\end{array}$ & $\begin{array}{c}\text { Silk cocoon } \\
\text { weight }(\mathbf{g m})\end{array}$ & $\begin{array}{c}\text { Silk shell } \\
\text { weight }(\mathbf{g m})\end{array}$ & $\begin{array}{c}\text { Silk ratio } \\
\mathbf{( \% )}\end{array}$ \\
\hline One time bed cleaning frequency per instar & $6.56 \pm 0.02 \mathrm{c}$ & $3.05 \pm 0.06 \mathrm{c}$ & $0.29 \pm 0.01 \mathrm{~d}$ & $9.61 \pm 0.15 \mathrm{~d}$ \\
Two times bed cleaning frequency per instar & $6.98 \pm 0.15 \mathrm{~b}$ & $3.12 \pm 0.05 \mathrm{cb}$ & $0.313 \pm 0.003 \mathrm{c}$ & $10.09 \pm 0.03 \mathrm{c}$ \\
Three times bed cleaning frequency per instar & $8.3 \pm 0.10 \mathrm{a}$ & $3.24 \pm 0.09 \mathrm{ab}$ & $0.38 \pm 0.005 \mathrm{~b}$ & $11.73 \pm 0.19 \mathrm{~b}$ \\
once bed cleaning frequency per day & $8.35 \pm 0.07 \mathrm{a}$ & $3.36 \pm 0.01 \mathrm{a}$ & $0.4 \pm 0 \mathrm{a}$ & $11.95 \pm 0.05 \mathrm{ab}$ \\
Twice bed cleaning frequency per day & $8.28 \pm 0.01 \mathrm{a}$ & $3.38 \pm 0.04 \mathrm{a}$ & $0.41 \pm 0 \mathrm{a}$ & $12.21 \pm 0.15 \mathrm{a}$ \\
No bed cleaning (control) & $5.9 \pm 0.03 \mathrm{~d}$ & $2.87 \pm 0.02 \mathrm{~d}$ & $0.246 \pm 0.003 \mathrm{e}$ & $8.72 \pm 0.16 \mathrm{e}$ \\
\hline
\end{tabular}

Kenyan Bivoltine Silkworm Races: The highest larval mortality $(3.6 \%$ to $30.06 \%)$ was registered when the larvae did not receive bed cleaning treatment in all level of larval instars except $1^{\text {st }}$ instar (Figure 4). Two times bed cleaning per instar $(1 \%)$ in $2^{\text {nd }}$ larval stage, three times bed cleaning per instar $(0.96 \%)$, one time bed cleaning per day $(0.8 \%)$ and two times bed cleaning per day $(0.53 \%)$ in $3^{\text {rd }}$ larval stage, once bed cleaning per day $(0.9 \%$ and $1.06 \%)$ and twice bed cleaning per day $(11.73 \%$ and $13 \%)$ in $4^{\text {th }}$ and $5^{\text {th }}$ larval stages respectively significantly reduced larval mortality rate (Figure 4). Though significant results were achieved in reducing larval mortality rate in the above bed cleaning frequencies the result suggested that two times bed cleaning frequency per instar for $2^{\text {nd }}$, three times bed cleaning per instar for $3^{\text {rd }}$ and once bed cleaning per day for $4^{\text {th }}$ and $5^{\text {th }}$ instars could be recommend to save time and labour.
The untreated control significantly $(P<0.05)$ reduced the important yield components of silkworm larvae as indicated by the short length of single spinning thread $(583 \mathrm{~m})$, smaller silk cocoon weight $(1.42 \mathrm{~g})$, and smaller silk shell weight $(0.263 \mathrm{~g})$. Significantly $(P<0.05)$ higher percentage of silk ratio was registered from one time bed cleaning frequency per day $(23 \%)$ and two times bed cleaning frequency per day $(22.45 \%)$ as opposed to the lowest percentage of silk ratio from the check $(18.49 \%)$. Significantly higher length of single spinning thread (915 $\mathrm{m}$ to $952 \mathrm{~m})$, big silk cocoon weight $(1.81 \mathrm{~g}$ to $1.82 \mathrm{~g}$ ) and big silk shell weight $(0.41 \mathrm{~g}$ to $0.42 \mathrm{~g})$ were obtained from the same treatments followed by three times cleaning frequency per instar larval developmental period for the same parameters (Table 3 ). 


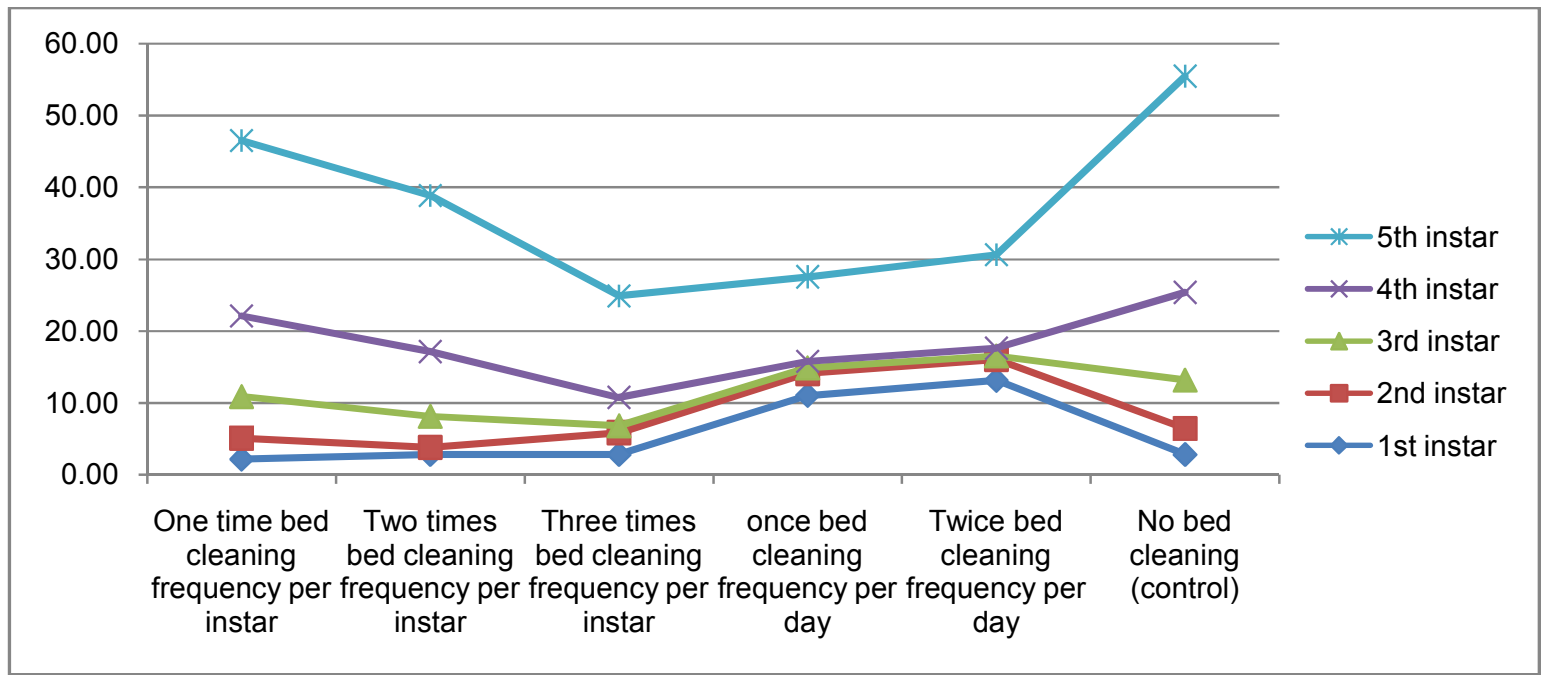

Figure 4: Effect of bed cleaning frequency on mortality of different larval instars of Kenyan bivoltine silkworm races

Table 3: Effect of bed cleaning frequency on the qualitative characters of the cocoon of Kenyan bivoltine silkworm races

\begin{tabular}{lcccc}
\hline \multicolumn{1}{c}{ Treatments } & $\begin{array}{c}\text { Length of silk } \\
\text { thread }(\mathbf{m})\end{array}$ & $\begin{array}{c}\text { Silk cocoon } \\
\text { weight }(\mathbf{g m})\end{array}$ & $\begin{array}{c}\text { Silk shell weight } \\
(\mathbf{g m})\end{array}$ & $\begin{array}{c}\text { Silk ratio } \\
(\%)\end{array}$ \\
\hline One time bed cleaning frequency per instar & $692.43 \pm 15.06 \mathrm{c}$ & $1.62 \pm 0.02 \mathrm{c}$ & $0.313 \pm 0.006 \mathrm{c}$ & $19.25 \pm 0.10 \mathrm{c}$ \\
Two times bed cleaning frequency per instar & $698.83 \pm 22.37 \mathrm{c}$ & $1.64 \pm 0.01 \mathrm{bc}$ & $0.316 \pm 0.003 \mathrm{c}$ & $19.35 \pm 0.25 \mathrm{c}$ \\
Three times bed cleaning frequency per instar & $854.56 \pm 19.62 \mathrm{~b}$ & $1.75 \pm 0.01 \mathrm{ba}$ & $0.387 \pm 0.006 \mathrm{~b}$ & $22.11 \pm 0.40 \mathrm{~b}$ \\
once bed cleaning frequency per day & $915.18 \pm 15.38 \mathrm{a}$ & $1.82 \pm 0.02 \mathrm{a}$ & $0.410 \pm 0.005 \mathrm{ba}$ & $22.45 \pm 0.08 \mathrm{ba}$ \\
Twice bed cleaning frequency per day & $952.17 \pm 30.16 \mathrm{a}$ & $1.81 \pm 0.01 \mathrm{a}$ & $0.420 \pm 0.005 \mathrm{a}$ & $23.00 \pm 0.35 \mathrm{a}$ \\
No bed cleaning (control) & $583.01 \pm 5.44 \mathrm{~d}$ & $1.42 \pm 0.07 \mathrm{~d}$ & $0.263 \pm 0.013 \mathrm{~d}$ & $18.49 \pm 0.07 \mathrm{~d}$ \\
\hline
\end{tabular}

Korean Bivoltine Silkworm Races: bed cleaning has no significant effect in all level of treatments on larval mortality rate of Korean silkworm races until the $3^{\text {rd }}$ larval instar. This indicates bed cleaning is not essential in $1^{\text {st }}$, $2^{\text {nd }}$ and 3rd larval stages. Percentage larval mortality rate in these life stages was less than $0.83 \%$. A significant effect among treatments was merely observed in $4^{\text {th }}$ and $5^{\text {th }}$ larval instars. A significant high mortality rate was recorded in the untreated control silkworm rearing beds during the above mentioned life stages. This was $13.83 \%$ and $32.83 \%$ respectively. Three times bed cleaning per instar $(1.66 \%)$, one time bed cleaning per day $(1.5 \%)$ and two times bed cleaning per day $(1 \%)$ in $4^{\text {th }}$ larval stage, once bed cleaning per day $(0.83 \%)$ and twice bed cleaning per day $(0.5 \%)$ in $5^{\text {th }}$ larval stage caused a statistically low mortality rate (Figure 5 ).

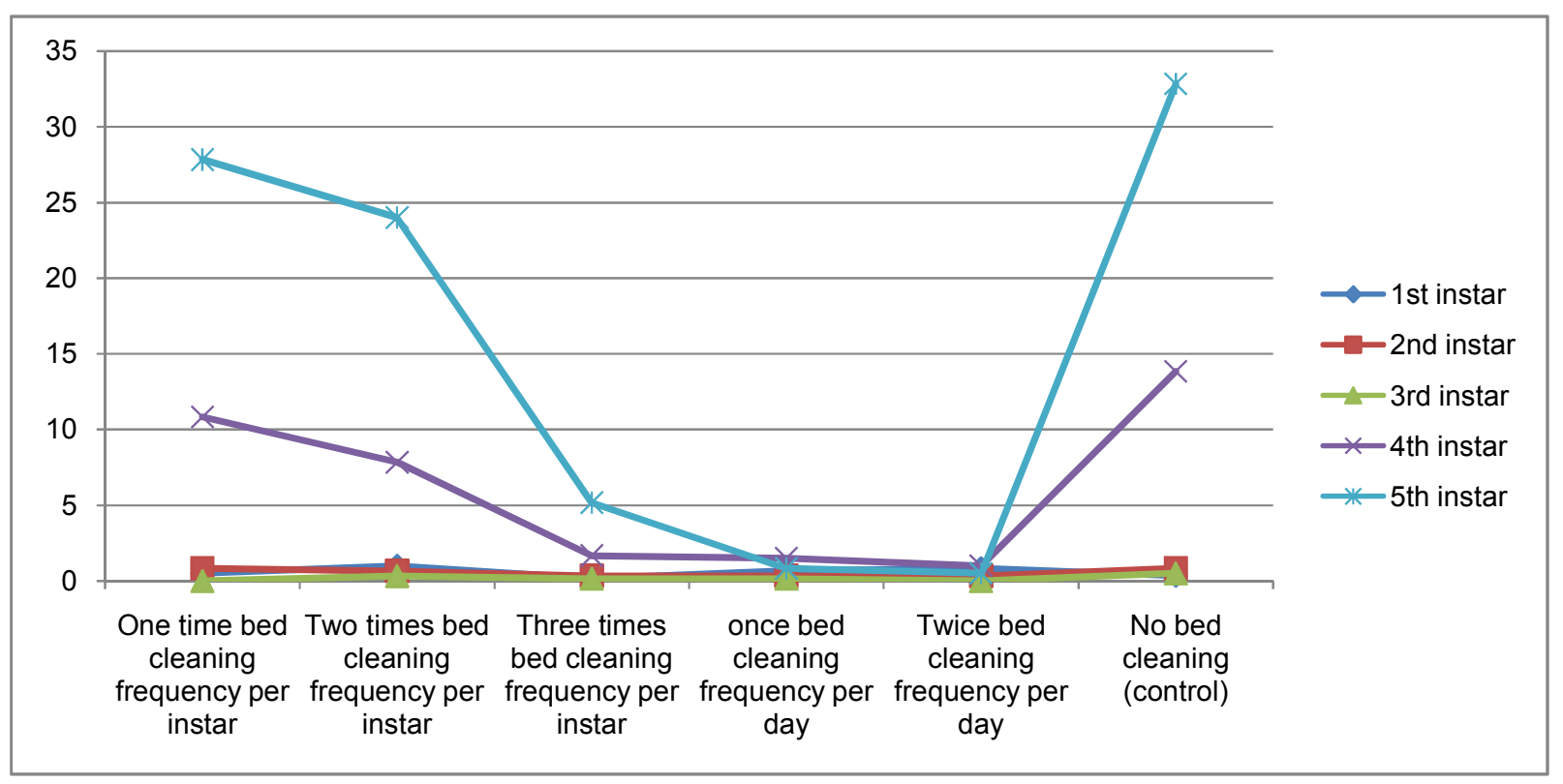

Figure 5: Effect of bed cleaning frequency on mortality of different larval instars of Korean bivoltine silkworm races 
Abiy Tilahun et al.,

The length of spinning silk thread, silk Cocoon weight, silk Shell weight and Silk ratio produced from Korean bivoltine silkworm races were $611 \mathrm{~m}, 1.45 \mathrm{~g}, 0.27 \mathrm{~g}$ and $19 \%$ in the untreated check for the above order, while in the least effective cleaning frequency treatment (one time bed cleaning frequency per instar of larval growth period) this was $673 \mathrm{~m}, 1.65 \mathrm{~g}, 0.33 \mathrm{~g}$, and $20.26 \%$ in the same
Sci. Technol. Arts Res. J., April-June 2015, 4(2): 39-47

order (Table 4). Once bed cleaning per day and twice bed cleaning per day were significantly $(P<0.05)$ superior than other treatments in improving length of spinning thread $(950 \mathrm{~m}$ and $961 \mathrm{~m})$, Cocoon weight $(1.81 \mathrm{~g}$ and $1.77 \mathrm{~g})$ Shell weight $(0.42$ and $0.40 \mathrm{~g})$ and Silk ratio $(23.03 \%$ and $22.31 \%$ ) respectively (Table 4 ).

Table 4: Effect of bed cleaning frequency on the qualitative characters of the cocoon of Korean bivoltine silkworm races

\begin{tabular}{|c|c|c|c|c|}
\hline Treatments & $\begin{array}{l}\text { Length of silk } \\
\text { thread }(\mathrm{m})\end{array}$ & $\begin{array}{l}\text { Silk cocoon } \\
\text { weight (gm) }\end{array}$ & $\begin{array}{c}\text { Silk shell } \\
\text { weight (gm) }\end{array}$ & $\begin{array}{c}\text { Silk ratio } \\
(\%)\end{array}$ \\
\hline One time bed cleaning frequency per instar & $673.66 \pm 20.43 \mathrm{dc}$ & $1.65 \pm 0.02 b$ & $0.337 \pm b$ & $20.26 \pm b$ \\
\hline Two times bed cleaning frequency per instar & $719.00 \pm 22.23 c$ & $1.68 \pm 0.05 \mathrm{ba}$ & $0.347 \pm b$ & $20.41 \pm b$ \\
\hline Three times bed cleaning frequency per instar & $796.33 \pm 46.81 b$ & $1.80 \pm 0.04 a$ & $0.357 \pm b$ & $19.48 \pm c b$ \\
\hline once bed cleaning frequency per day & $950.66 \pm 19.06 a$ & $1.81 \pm 0.05 a$ & $0.420 \pm a$ & $23.03 \pm a$ \\
\hline Twice bed cleaning frequency per day & $961.00 \pm 17.61 \mathrm{a}$ & $1.77 \pm 0.02 \mathrm{ba}$ & $0.400 \pm a$ & $22.31 \pm a$ \\
\hline No bed cleaning (control) & $611.66 \pm 13.86 d$ & $1.45 \pm 0.09 c$ & $0.277 \pm c$ & $19.00 \pm c$ \\
\hline
\end{tabular}

Vietnamese Multivoltine Silkworm Races: There was high larval mortality rate in some of the treated larvae than the untreated one in $1^{\text {st }}$ instar larvae. This could be explained by the existence of other larval death causes such as mechanical damage of worms while feeding and bed cleaning practices. In the $2^{\text {nd }}$ instar there was no much variability among the treatments with regard to larval mortality rate. A significant bed cleaning effect was not found in the $3^{\text {rd }}$ and $4^{\text {th }}$ instar larval growth by which larval mortality rate was not exceeded $0.83 \%$. However mortality was drastically increased $(45.5 \%)$ during the $5^{\text {th }}$ larval stage in the untreated control. Mortality was reduced to $0.66 \%$ in three times bed cleaning per instar and once bed cleaning per day .No larval mortality bring into being from twice bed cleaning frequency per day treated rearing beds (Figure 6).

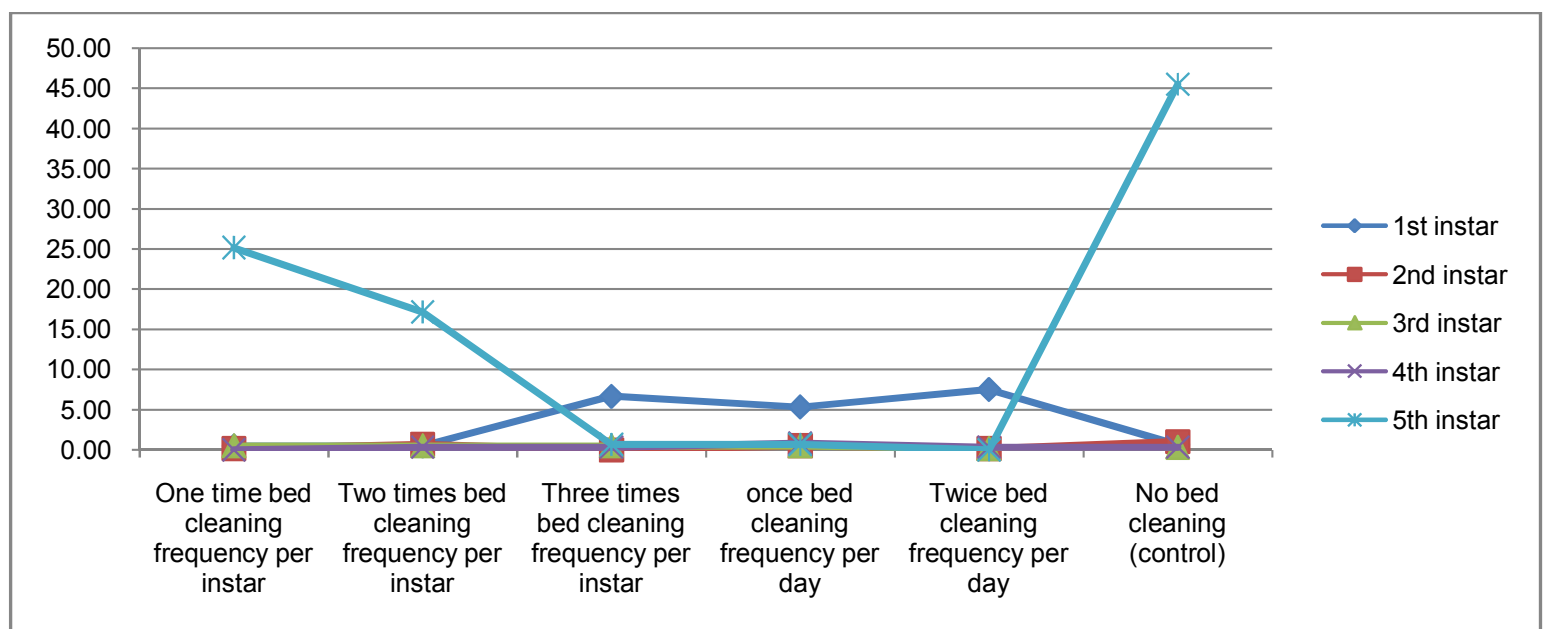

Figure 6: Effect of bed cleaning frequency on mortality of different larval instars of Vietnamese multivoltine silkworm races

Length of spinning silk thread (684 to 954 meters), Shell weight (0.303 to $0.377 \mathrm{gms})$ and Silk ratio (18.77 to $22.29 \%)$ (Table 5 ) were significantly $(P<0.05)$ higher in the treated silkworm larvae than the untreated one $(666 \mathrm{~m}$, $0.27 \mathrm{gms}$, and $18.59 \%$ respectively). Superior results were obtained from once bed cleaning frequency per day, twice bed cleaning frequency per day, and three times bed cleaning frequency per instar of silkworm larval growth period. Therefore we can use three times bed cleaning frequency per instar which is the least frequent bed cleaning interval among others to reduce larval mortality rate and to gain better silk cocoon yield.

Table 5: Effect of bed cleaning frequency on the qualitative characters of the cocoon of Vietnamese multivoltine silkworm races

\begin{tabular}{lcccc}
\hline \multicolumn{1}{c}{ Treatments } & $\begin{array}{c}\text { Length of silk } \\
\text { thread }(\mathbf{m})\end{array}$ & $\begin{array}{c}\text { Silk cocoon } \\
\text { weight } \\
\text { (gm)ns }\end{array}$ & $\begin{array}{c}\text { Silk shell } \\
\text { weight (gm) }\end{array}$ & $\begin{array}{c}\text { Silk ratio } \\
\text { (\%) }\end{array}$ \\
\hline One time bed cleaning frequency per instar & $684.33 \pm 16.79 \mathrm{c}$ & $1.59 \pm 0.07$ & $0.303 \pm 0.020 \mathrm{bc}$ & $19.00 \pm 0.34 \mathrm{~b}$ \\
Two times bed cleaning frequency per instar & $772.33 \pm 54.75 \mathrm{bc}$ & $1.64 \pm 0.11$ & $0.3100 \pm 0.017 \mathrm{bc}$ & $18.77 \pm 0.19 \mathrm{~b}$ \\
Three times bed cleaning frequency per instar & $895.00 \pm 90.50 \mathrm{ba}$ & $1.62 \pm 0.11$ & $0.360 \pm 0.015 \mathrm{ba}$ & $22.29 \pm 0.93 \mathrm{a}$ \\
once bed cleaning frequency per day & $954.67 \pm 40.06 \mathrm{a}$ & $1.72 \pm 0.01$ & $0.377 \pm 0.003 \mathrm{a}$ & $21.86 \pm 0.35 \mathrm{a}$ \\
Twice bed cleaning frequency per day & $925.67 \pm 41.98 \mathrm{a}$ & $1.65 \pm 0.06$ & $0.367 \pm 0.013 \mathrm{ba}$ & $22.13 \pm 0.26 \mathrm{a}$ \\
No bed cleaning (control) & $666.33 \pm 11.83 \mathrm{c}$ & $1.46 \pm 0.22$ & $0.270 \pm 0.040 \mathrm{c}$ & $18.59 \pm 0.46 \mathrm{~b}$ \\
\hline
\end{tabular}


Abiy Tilahun et al.,

Sannappa and Jayaramaiah (1999) reported that as soon as the larvae grow-up, the unconsumed leaves and litter increase in the rearing bed which ultimately cause changing atmosphere and favoring multiplication of pathogenic organisms such as protozoa, fungi, bacteria and viruses. They further mentioned that due importance towards strict adherence to maintenance of hygienic conditions in and around the rearing house are a prerequisite for a successful cocoon harvest. So, ideal rearing condition such as bed spacing and bed cleaning should be done as per the different instars of larval stages and silkworm breeds. This study also confirmed there was variability in larval mortality rate among instars of different silkworm races in respective with various bed cleaning treatments. The results showed that bed cleaning caused significant reduction in larval mortality due to diseases against the control in all silkworm races. Silkworm diseases observed during our study were bacterial, fungal, and viral diseases. Rearing under better feeding and bed cleaning, ensuring pathogen free rearing conditions are some of the vital requirements for the growth of healthy worms that enables the silkworm tolerate adverse conditions. Periodic removal of bed refuse and fecal matter ensures good bed hygiene, prevention of diseases and good larval growth. The pilling of litter makes beds moist became favoring for multiplication of pathogenic microorganisms affects the health of worms and culture (Sannappa and Jayaramaiah 1999).

Devaiah et al. (1985) reported that feeding and cleaning are important silkworm management practices affecting the larval weight, silk gland weight, cocoon weight and shell weight considerably. Their observation on different bed cleaning frequencies indicated that once and twice bed cleaning treatments caused less mortality and greater effective rate of rearing compared to other treatments and these are statistically significant. Though these bed cleaning frequencies were consuming more time and labor they can resulting in less larval mortality and maximum effective rate of rearing. In our study the cocoon characters after the $5^{\text {th }}$ instar was treated in once and twice bed cleaning treatments providing supportive evidence for good rearing condition, also statistically significant compared to other types of bed cleaning frequencies on many parameters. Bed cleaning experiment revealed that once bed cleaning per day, twice bed cleaning per day followed by three times bed cleaning per instar treatments were statistically superior in terms of minimum larval mortality, shorter larval period, longer silk thread, bigger cocoon weight, bigger silk shell weight and maximum percentage silk ratio depending on the successive larval stages of silkworm races (Tables 1 to 5). After successful silkworm rearing such as ideal bed cleaning, cocoon weight gain was recorded in previous findings. This difference in cocoon weight gain may be attributed to the difference in the bed cleaning treatments selected for the study and it may be inferred that treatments are a better performer than the control. Results from our study revealed that higher effective rate of rearing, higher cocoon weight; shell weight and silk ratio were obtained in the treatment against the control in all silkworm races. The findings of our study are in agreement with those of Joshi and Misra (1982); Hajarika et al., (2003). They found that higher effective rate of rearing, cocoon weight, shell weight and shell ratio were achieved in the bed cleaning treatments against the control. This was achieved by integration of not a single
Sci. Technol. Arts Res. J., April-June 2015, 4(2): 39-47

but a multitude of approaches viz. proper disinfection of the rearing room and appliances, use of bed disinfectant, bed spacing, bed cleaning and feeding as per recommendations. Prevention is better than Cure" is the correct approach and that should be adopted in integrated silkworm rearing management (Nataraju et al., 2005). This means that one should go about actively preventing diseases before it occurs, and it is only when preventive measures are in force that we can hope to effectively control the occurrence and spread of diseases. Patil et al., (2009) observed that eri silkworms receiving ideal bed cleaning treatment showed significantly higher larval weight $(7.904 \mathrm{~g})$, effective rate of rearing $(90.0 \%)$, cocoon weight $(3.683 \mathrm{~g})$, shell weight $(0.426 \mathrm{~g})$, shell ratio $(13.31 \%)$, pupal weight $(3.256 \mathrm{~g})$ with lower larval and pupal durations. Reddy et al., (1989b) recorded survival rate $(95.67 \%)$, shell ratio $(12.20 \%)$, and shorter developmental period (26.49 days) when eri silkworms were reared on ideal bed cleaning treatment. In Our study results indicating that the maximum shell weight $(0.436 \mathrm{~g})$, silk ratio $(12.82 \%)$ and cocoon weight $(3.44 \mathrm{~g})$ have been obtained in eri silkworm shelf rearing method. Devaiah et al., (1985) reported that feeding, bed spacing and bed cleaning are important worm management practices affecting the larval weight, silk gland weight, cocoon weight and shell weight considerably. According to them maximum larval weight $(7.6 \mathrm{~g})$, cocoon weight $(2.96 \mathrm{~g})$ ,effective rate of rearing $(90.0 \%)$, shell weight $(0.44 \mathrm{~g})$ and silk ratio $(14.9 \%)$ has been obtained in shelf method of rearing on castor.

\section{CONCLUSIONS}

This study confirmed that, once bed cleaning frequency per day, twice bed cleaning frequency per day and three times bed cleaning frequency per instar significantly shortened the larval period of Vietnamese erisilkworm races, Indian eri silkworm races, Kenyan bivoltine silkworm races, Korean bivoltine silkworm races and Vietnamese multivoltine silkworm races. Larval mortality was significantly higher in all the tested silkworm races of the $4^{\text {th }}$ and $5^{\text {th }}$ larval instars in the control beds. Among the tested treatments, one time bed cleaning frequency per day, two times bed cleaning frequency per day and three times bed cleaning frequency per instar, significantly reduced larval mortality rate during the $4^{\text {th }}$ and $5^{\text {th }}$ larval instars of all silkworm races. The young larval stages $\left(1^{\text {st }}, 2^{\text {nd }}\right.$, and $3^{\text {rd }}$ instars $)$ showed low larval mortality rate than the mature larval stages $\left(4^{\text {th }}\right.$ and $5^{\text {th }}$ larval instars). Bed cleaning frequencies had no significant effect for $1^{\text {st }}$ larval instar in all silkworm races. All bed cleaning frequencies had no significant effect for Korean silkworm races and Vietnamese multivoltine silkworm races until the $3^{\text {rd }}$ larval instars. Hence, bed cleaning is not necessary during these stages in silk worm rearing practices for such races. Bed cleaning has showed a positive effect to reduce larval mortality rate for Vietnamese eri-silkworm races, Indian eri-silkworm races and Kenyan bivoltine silkworm races during $2^{\text {nd }}$ and $3^{\text {rd }}$ larval growth. The grown up worms, after completing feeding during late fifth instar at their ripened stage (ready to spin silk) are the once to be transferred on mountages for spinning silk cocoon. Bed cleaning is an important silkworm rearing process to ensure good hygiene and better feeding appetite especially during the $5^{\text {th }}$ larval instar to obtain better cocoon yield components of silkworm races. In this regard, long spinning silk thread, robust silk cocoon and shell weight and higher percentage of silk ratio of silkworms were registered from one time 
Abiy Tilahun et al.,

bed cleaning frequency per day and two times bed cleaning frequency per day in the ripened stage of silkworm larvae for Vietnamese eri-silkworm races, Indian eri silkworm races, Kenyan bivoltine silkworm races, Korean bivoltine silkworm races. For Vietnamese multivoltine silkworm races better results for the same parameters were obtained from three times bed cleaning frequency per instar in addition to one time bed cleaning frequency per day and two times bed cleaning frequency per day. Though the above mentioned three treatments are superior in reducing larval mortality and increasing yield components of silkworm races, one time bed cleaning frequency per day and three times bed cleaning frequency per instar could be recommended to save time and labor for silk growers to ensure higher cocoon yield depending on the type of silkworm races. From this study it can be concluded that, if proper bed cleaning is not done in time it leads to various complications viz. ill health of larvae, disinterest of the larvae to feed due to unhygienic conditions, ultimately worms become weak and low in productivity. To this effect, stage wise bed cleaning frequency for each larval instar of the different silkworm races should be done to reduce larval mortality, to shortened larval period and to improve the yield components of the different silkworm races.

\section{Acknowledgment}

The execution of this study was made possible with the financial support of Ethiopian Institute of Agricultural Research through Melkassa research center. I owe my appreciation for Jemanesh Demisse, Shito Tufa, Etaferahu Getachew and Asasu Belihu for their unreserved assistances during managing the silkworm rearing practices.

\section{Conflict of Interest}

Conflict of interest none declared.

\section{REFERENCES}

Dayashankar, K.N. (1982). Performance of eri silkworm, Samia cynthia ricini Boisduval on different host plants and economics of rearing on castor under Dharwad conditions. M.Sc. Thesis, University of Agricultural Sciences, Bangalore, pp.60-86.

Devaiah, M.C., Rajashekar Gouda, R.,Yelshetty Suhas and Govindan, R. (1985). Growth and Silk Production in Samiya cynthia ricini Boisduval (Lepidoptera: Saturniidae) Fed on Four Different Host Plants. Indian Journal of Sericulture 24: 33-35.

FAO (1976). Agricultural service Bulletin (15/1). Sericultural manual 1: Mulberry cultivation. Rome, Italy.

Gogoi, B. and Goswami, B.C. (1998). Studies on certain aspects of wild eri silkworm (Philosamia cynthia Drury) with special reference to its rearing performance. Sericologia 38:465-468. Krishnaswami, S. (1978). New Technology of Silkworm Rearing. Bulletin of the Center for Sericulture Research and Training Institute, pp. 1-24.

Hajarika, U., Barah, A., Phukan, J.C. and Benshamin, K.V. (2003). Study on the effect of different food plants and seasons on the larval development and cocoon characters of silkworm Samia cynthia ricini Boisduval. Bulletin of the Indian Academy of Sericulture 7: 77-85.

Hisao Aruga. (2001). Principles of sericulture. $3^{\text {rd }}$ ed. Oxford \& IBH publishing Co. Pvt. Ltd., New Delhi. Pp.267-270.

Joshi, K.L. (1987). Progression Factor for Growth in Eri Silk Moth in Relation to Diet. Indian Journal of Sericulture 26: 98-99.
Sci. Technol. Arts Res. J., April-June 2015, 4(2): 39-47

Joshi, K.L. and Misra, S.D. (1982). Silk Percentage and effective rate of rearing of eri silkmoth, Philosamia ricini Hutt. (Lepidoptera: Saturniidae). Entomology 7:107-110.

Metaferia, H.Y., Amanuel, T. and Kedir, S. (2007). Scaling up of silk production technologies for employment and income generation in Ethiopia. In: Success with Value Chain: proceedings of scaling up and scaling out of agricultural technologies in Ethiopia, an international conference, 9-11 May 2006 (Tsedeke Abate ed). Ethiopian Institute of Agricultural Research, Addis Ababa.

Nataraju, B., Sathyaprasad, K., Manjunath, D. and Kumar, C. A. (2005). Silkworm Crop Protection. Central Silk Board, Bangalore. 412pp.

Neelu Nangia., Jagadish, P.S. and Nageshchandra, B.K (2000). Evaluation of the Volumetric Attributes of the Eri Silkworm Reared on Various Host Plants. International Journal of Wild Silkmoth \& Silk 5: 36-38.

Patil, R.R., Kusugal, S. and Ankad, G. (2009). Performance of eri silkworm, Samia cynthia ricini Boisd. on few food plants. Karnataka Journal of Agriculture Science 22:210221.

Raghavaiah, C.V. (2003b). Prospects of Eri silk (Philosomia ricini) production along with castor beans (Ricinus communis L.) and Tapioca (Manihot utilisimma) production in Andhra Pradesh. Indian Silk 42: 33-35

Reddy, D.N.R., Kotikal, Y.K. and Vijayendra, M. (1989b). Development and Silk Yield of Eri Silkworm, Samia Cynthia ricini (Lepidoptera: Saturnidae) as Influenced by the Food Plants. Mysore Journal of Agriculture Science 23: $506-508$.

Reddy, D.N. and Swamy, K.C. (1999). Effect of host on the consumption rate, leaf - cocoon and leaf egg ratio of eri silkworm, Samia cynthia ricini Boisduval (Lepi doptera:Saturniidae). Entomology 24: 67-70.

Reddy, R.M. (2008). Value addition span for silkworm cocoon - time for utility optimization. International Journal of Industrial Entomology 17:109-113.

Sachan, J.N. and Bajpai, S.P (1973a). Response of Castor (Ricini communis L.) Varieties on Growth and Silk Production of Eri Silkworm Philosamia ricini Hutt. (Saturniidae). Annals of Arid Zone 11:112-115.

Sakthivel, N. (2004). Eri culture on castor and tapioca in Tamil Nadu. In:Proceeding on workshop of prospects and development of ericulture, University of Agricultural Sciences, Dharwad, pp. 78-81.

Sannappa, B. and Jayaramaiah, J. (1999). Mineral Constituents of Selected Genotypes of Castor, Ricinus communis L. Mysore Journal of Agriculture Science 33: 157-161.

Sarkar, D.C. (1988). Ericulture in India. Central Silk Board, Grafo Printers, pp.1- 49.

Sharma, R.K., Dutta, S.K. and Bhuyan, C. (1996). Effect of Food Plants on Certain Life Parameters of Eri Silkworm (Philosamia ricini). Journal of Applied Biology 6(1-2):11520.

Singh, K.C. and Benchamin, K.V. (2002). Biology and ecology of the eri silkmoth Samia ricini Donovan (Saturniidae): Bulletein of the Indian Academy of Sericulture 6: 20-33.

Takano, K. and Arai, N. (1978). Studies on the food values on the basis of feeding and cocoon productivity in the silkworm, Bombyx mori. Sericolture Science 47: 134-142.

Zhang, Y.H., Xu, A.Y., Wei, Y.D., Li, M.W., Hou, C.X. and Zhang, G.Z. (2002). Studies on feeding habits of silkworm germplasm resources for artificial diet without mulberry. Acta Sericologia Sinica 28: 333-336. 